Proceedings

\title{
Uncommon Coordination Modes of a Potential Heptadentate Aminophenol Donor ${ }^{+}$
}

\author{
Julio Corredoira-Vázquez *, Cristina González-Barreira, Ana M. García Deibe, \\ Jesús Sanmartín-Matalobos and Matilde Fondo \\ Departamento de Química Inorgánica, Facultade de Química, Universidade de Santiago de Compostela, \\ Santiago de Compostela 15782, Spain; cristina.gonzalez.barreira@rai.usc.es (C.G.-B.); \\ ana.garcia.deibe@usc.es (A.M.G.D.); jesus.sanmartin@usc.es (J.S.-M.); matilde.fondo@usc.es (M.F.) \\ * Correspondence: julio.corredoira.vazquez@usc.es; Tel.: +34-881814248 \\ + Presented at the 24th International Electronic Conference on Synthetic Organic Chemistry, \\ 15 November-15 December 2020; Available online: https://ecsoc-24.sciforum.net/.
}

Received: date; Accepted: date; Published: date

\begin{abstract}
This work describes the synthesis, characterization and reactivity towards $\mathrm{Ho}^{\mathrm{III}}$ of a potential heptadentate $\mathrm{N}_{4} \mathrm{O}_{3}$ aminophenol donor. The crystal structure of the $\left[\mathrm{Ho}\left(1,1,4-\mathrm{H}_{3} \mathrm{~L}\right)\left(1,1,4-\mathrm{H}_{6} \mathrm{~L}\right)\right] \quad$ complex $\quad\left(1,1,4-\mathrm{H}_{6} \mathrm{~L} \quad=\quad 6,6^{\prime}-\left(2-\left(5-\right.\right.\right.$ bromo-2-hydroxy $^{2}$ -3-nitrobenzyl)-2,5,8,11-tetraazadodecane-1,12-diyl)bis(4-bromo-2-nitrophenol)) shows that the holmium atom binds two aminophenol ligands, one acting as trianionic hexadentate, and the other one as neutral monodentate. As far as we know, both coordination modes of the aminophenol are hitherto unknown for this kind of scarcely reported ligand. This leads to coordination number 7 for the $\mathrm{Ho}^{\mathrm{III}}$ ion, which is in a capped trigonal prism environment.
\end{abstract}

Keywords: aminophenol; potential heptadentate donor; holmium

\section{Introduction}

Since the discovery of the first single-ion magnet (SIM) in 2003 [1], the bis-phthalocyanine terbium complex $\left[\mathrm{Tb}\left(\mathrm{Pc}_{2}\right]\right.$, the field of molecular magnetism began to focus on the coordination chemistry of lanthanoid elements. These elements, by themselves, fulfil two of the necessary requirements for a molecule to behave like a magnet: they present intrinsic anisotropy, and, usually, they have a high spin ground state. However, according to Reinhart and Long [2], the anisotropy of the molecule is modulated by the interaction between the single-ion electron density and the crystal field environment in which it is placed. In this sense, for oblate ions, like $\mathrm{Dy}^{\mathrm{III}}$ or $\mathrm{Ho}^{\mathrm{III}}$, a strong axial crystal field should maximize the uniaxial anisotropy. In this way, it has been demonstrated that an axial pentagonal bipyramidal ( $\mathrm{pbp}$ ) environment usually increases the anisotropy of the complexes, improving their magnetic properties. Accordingly, the blocking temperature record for an air-stable molecular magnet $(20 \mathrm{~K})$ is held by a dysprosium(III) complex with pbp geometry [3]. Nevertheless, this temperature is still very low and, consequently, more research in the coordination chemistry of lanthanoid complexes with ligands that can lead to pbp geometries is still needed, in order to improve the magnetic behaviour of this kind of complex. With these considerations in mind, in this study we describe the synthesis of a new potentially heptadentate ligand, which could predetermine a pbp geometry by itself, and its reactivity towards holmium(III).

\section{Materials and Methods}

\subsection{Materials and General Methods}


All chemical reagents and solvents were purchased from commercial sources and used as received without further purification. Elemental analyses of $\mathrm{C}, \mathrm{H}$ and $\mathrm{N}$ were performed on a THERMOSCIENTIFC FLASH SMART analyzer. ${ }^{1} \mathrm{H}-\mathrm{NMR}$ spectrum of $3 \mathrm{NO}_{2}, 5 \mathrm{Br}-\mathrm{H}_{3} \mathrm{~L}$ and $3 \mathrm{NO}_{2,5}, 5 \mathrm{Br}-\mathrm{H}_{6} \mathrm{~L}^{1,1,4}$ were recorded on a Varian Inova 400 spectrometer, using DMSO-d 6 as solvent. Infrared spectrum of $3 \mathrm{NO}_{2}, 5 \mathrm{Br}-\mathrm{H}_{3} \mathrm{~L}$ was recorded in the ATR mode on a Varian $670 \mathrm{FT} / \mathrm{IR}$ spectrophotometer in the range $4000-500 \mathrm{~cm}^{-1}$.

Single X-ray data for $\left[\mathrm{Ho}\left(3 \mathrm{NO}_{2,5}, 5 \mathrm{Br}-\mathrm{H}_{3} \mathrm{~L}^{1,1,4}\right)\left(3 \mathrm{NO}_{2,5} \mathrm{Br}-\mathrm{H}_{6} \mathrm{~L}^{1,1,4}\right)\right] \cdot 1.5 \mathrm{CH}_{3} \mathrm{C}_{6} \mathrm{H}_{5} \quad\left(2 \cdot 1.5 \mathrm{CH}_{3} \mathrm{C}_{6} \mathrm{H}_{5}\right)$ were collected at $100 \mathrm{~K}$ on a Bruker D8 VENTURE PHOTON III-14 diffractometer, employing graphite monochromated Mo-k $\alpha(\lambda=0.71073 \AA)$ radiation. Multi scan absorption corrections were applied using SADABS [4]. The structure was solved by standard direct methods, employing SHELXT [5], and then refined by full matrix least-squares techniques on $\mathrm{F}^{2}$, using SHELXL from the program package SHELX 2018 [5].

\subsection{Syntheses}

$3 \mathrm{NO}_{2,5}, 5 \mathrm{Br}-\mathrm{H}_{3} \mathrm{~L}$ : A solution of 5-bromo-2-hidroxi-3-nitrobenzaldehido $(97 \%, 0.500 \mathrm{~g}, 1.971 \mathrm{mmol})$ in methanol $(20 \mathrm{~mL})$ and a solution of triethylentetramine $(98 \%, 0.100 \mathrm{~g}, 0.657 \mathrm{mmol})$ in methanol (20 $\mathrm{mL}$ ) are mixed under stirring. The mixture is stirred at room temperature for $4 \mathrm{~h}$ and an orange solid precipitates. The solid is filtered and dried in an oven. Yield: $0.428 \mathrm{~g}(78 \%) . \mathrm{Mm}: 830.24 \mathrm{~g} / \mathrm{mol}$. Elemental analysis calcd. for $\mathrm{C}_{27} \mathrm{H}_{24} \mathrm{~N}_{7} \mathrm{O}_{9} \mathrm{Br}_{3}$ : C 39.06, N 11.81, H 2.91\%. Found: C 38.48, N 12.05, H 2.82. IR spectrum (ATR, $\left.\tilde{v} / \mathrm{cm}^{-1}\right): 1646[v(\mathrm{C}=\mathrm{Nimin})], 3075[v(\mathrm{OH})] .{ }^{1} \mathrm{H}-\mathrm{RMN}\left(400 \mathrm{MHz}, \mathrm{DMSO}-d_{6}\right.$,

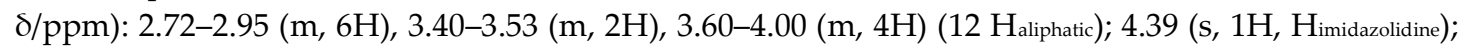
$7.58(\mathrm{~s}, 1 \mathrm{H}), 7.68(\mathrm{~s}, 2 \mathrm{H}), 7.82(\mathrm{~s}, 1 \mathrm{H}), 8.08(\mathrm{~s}, 2 \mathrm{H})\left(6\right.$ Haromatic); $8.41\left(\mathrm{~s}, 2 \mathrm{H}, 2 \mathrm{H}_{\text {imine }}\right)$.

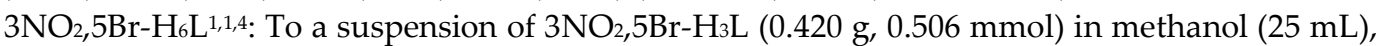
$\mathrm{NaBH}_{4}(0.115 \mathrm{~g}, 3.036 \mathrm{mmol})$ is added in small portions for $15 \mathrm{~min}$. The mixture is stirred for $2 \mathrm{~h}$, and the obtained solution is concentrated up to $1 / 2$ of its initial volume. The precipitated orange solid is filtered and dried in air. Yield: $0.175 \mathrm{~g}(41 \%)$. M.W.: $836.29 \mathrm{~g} / \mathrm{mol} .{ }^{1} \mathrm{H}-\mathrm{RMN}\left(400 \mathrm{MHz}, \mathrm{DMSO}-\mathrm{d}_{6}\right.$, ठ/ppm): 2.32-2.41 (m, 2H), 2.80-2.91 (m, 4H), 3.34-3.50 (m, 4H), (H1-H3, H1'-H3'); 3.95 (s, 2H, H4), $4.18(4 \mathrm{H}, \mathrm{s}, \mathrm{H} 4$ ) ) 7.17 (s, 1H, H6), 7.49 (s, 2H, H12), 7.72 (s, 1H, H8), 7.90 (s, 2H, H14).

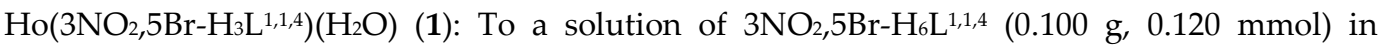
acetonitrile/chloroform $(20 / 15 \mathrm{~mL})$ triethylamine $(0.036 \mathrm{~g}, 0.359 \mathrm{mmol})$ is added. Then, this solution is mixed with an acetonitrile $(15 \mathrm{~mL})$ solution of holmium nitrate pentahydrate $(0.053 \mathrm{~g}, 0.120$ $\mathrm{mmol}$ ). The mixture is stirred for $24 \mathrm{~h}$, and it is centrifuged to eliminate any possible impurity. The decanted liquid is concentrated in a rotary evaporator, and a solid precipitates. The solid is collected by filtration and dried in an oven for $4 \mathrm{~h}$. Yield: $0.056 \mathrm{~g}(47 \%)$. Elemental analysis calcd. for $\mathrm{C}_{27} \mathrm{H}_{26} \mathrm{Br}_{3} \mathrm{HoN}_{7} \mathrm{O}_{10}$ (1013.14): C 32.01, N 9.68, H 2.59\%. Found: C 32.59, N 9.85, H 2.43\%.

Recrystallization of the crude product in toluene yields single crystals, suitable for $\mathrm{X}$-ray diffraction studies, of the by-product $\left[\mathrm{Ho}\left(3 \mathrm{NO}_{2}, 5 \mathrm{Br}-\mathrm{H}_{3} \mathrm{~L}^{1,1,4}\right)\left(3 \mathrm{NO}_{2}, 5 \mathrm{Br}-\mathrm{H}_{6} \mathrm{~L}^{1,1,4}\right)\right] \cdot 1.5 \mathrm{CH}_{3} \mathrm{C}_{6} \mathrm{H}_{5}$ (2-1.5 $\left.\mathrm{CH}_{3} \mathrm{C}_{6} \mathrm{H}_{5}\right)$. Crystal data (at 100(2) K): monoclinic, I2/a, $\mathrm{C}_{64.5} \mathrm{H}_{68} \mathrm{Br}_{6} \mathrm{HoN}_{14} \mathrm{O}_{18}, \mathrm{MW}=1971.71$, with

$a=18.9091(18) \AA, b=31.024(3) \AA, c=31.734(4) \AA, \beta=94.779(2) \stackrel{\circ}{\circ}, V=18551(3) \AA^{3}, Z=8 ; R_{1}=0.0628$ and $w R_{1}=0.1568(\mathrm{I}>2 \sigma \mathrm{I})$.

\section{Results and Discussion}

\subsection{Synthesis}

The synthesis of the aminophenol ligand $3 \mathrm{NO}_{2}, 5 \mathrm{Br}-\mathrm{H}_{6} \mathrm{~L}^{1,1,4}$ (Scheme 1) requires the prior isolation of the Schiff base precursor $3 \mathrm{NO}_{2}, 5 \mathrm{Br}-\mathrm{H}_{3} \mathrm{~L}$. This latter was obtained by a previously reported method [6], in a typical Schiff condensation from the corresponding $3 \mathrm{NO}_{2}, 5 \mathrm{Br}$-salyciladehyde and triethylenetetramine (Scheme 1), but this Schiff base has not been described before, and it is original from this work. Its characterization by elemental analysis, IR and ${ }^{1} \mathrm{H}-\mathrm{NMR}$ spectroscopy (see experimental) agrees with its isolation with high purity. 


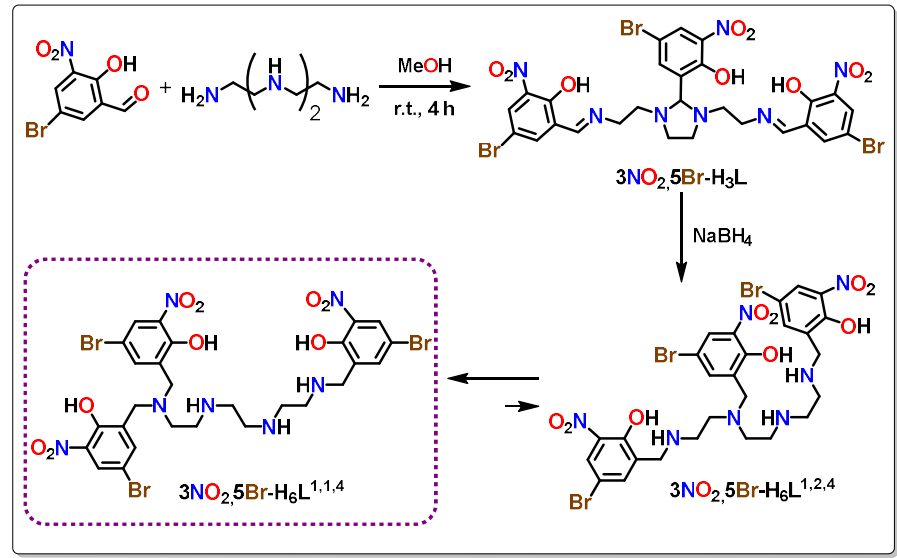

Scheme 1. Reaction scheme for isolation of aminophenol $3 \mathrm{NO}_{2}, 5 \mathrm{Br}-\mathrm{H}_{6} \mathrm{~L}^{1,1,4}$.

$3 \mathrm{NO}_{2,5} 5 \mathrm{Br}-\mathrm{H}_{6} \mathrm{~L}^{1,1,4}$ was obtained by reduction of $3 \mathrm{NO}_{2}, 5 \mathrm{Br}-\mathrm{H}_{3} \mathrm{~L}$ with $\mathrm{NaBH}_{4}$, as shown in Scheme 1 , and in spite of the possibility of obtaining a mixture of the isomers $3 \mathrm{NO}_{2}, 5 \mathrm{Br}-\mathrm{H}_{6} \mathrm{~L}^{1,1,4}$ and $3 \mathrm{NO}_{2,5}, 5 \mathrm{Br}-\mathrm{H}_{6} \mathrm{~L}^{1,2,4}$ (Scheme 1), as previously discussed for related aminophenols $[7,8]$, in this case the isomer $3 \mathrm{NO}_{2}, 5 \mathrm{Br}-\mathrm{H}_{6} \mathrm{~L}^{1,1,4}$ is isolated with high purity.

The exclusive formation of the $3 \mathrm{NO}_{2}, 5 \mathrm{Br}-\mathrm{H}_{6} \mathrm{~L}^{1,1,4}$ isomer is clearly seem in the ${ }^{1} \mathrm{H}-\mathrm{NMR}$ spectrum (Figure 1), which shows a single set of signals, and only four peaks in the aromatic region, in agreement with the equivalence of 2 aromatic rings, while three inequivalent aromatic rings (as it

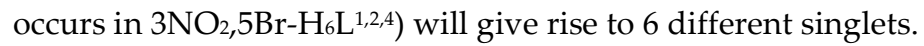

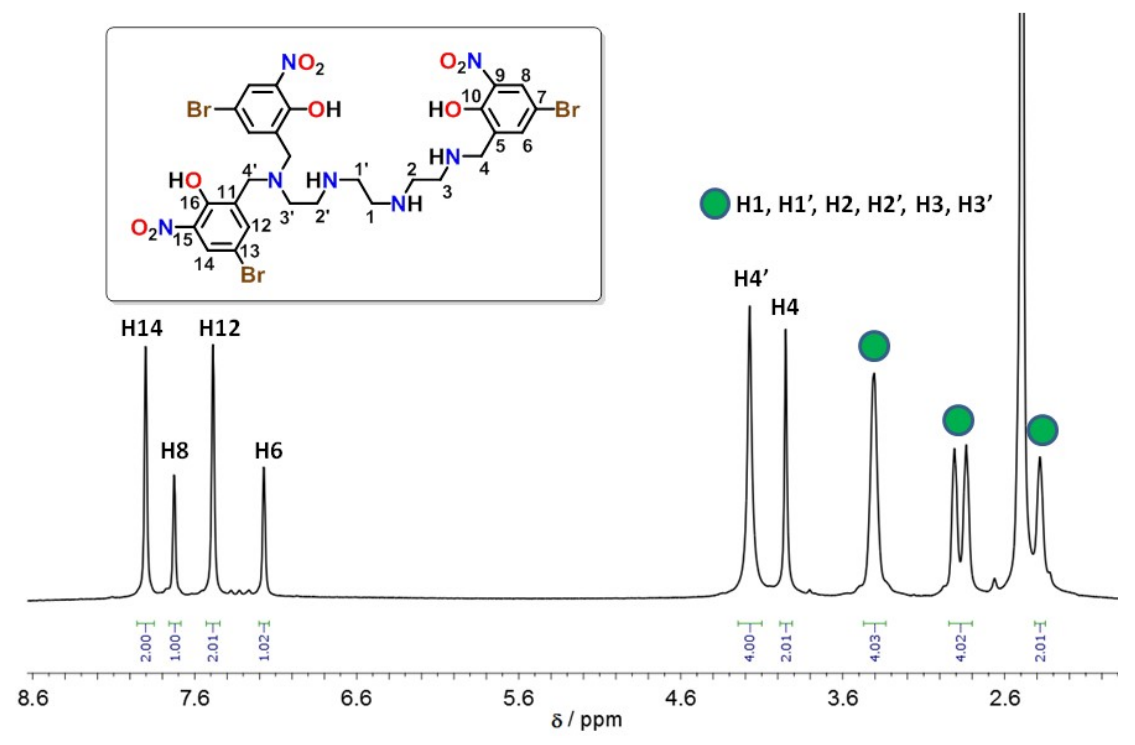

Figure 1. ${ }^{1} \mathrm{H}-\mathrm{NMR}$ spectrum for $3 \mathrm{NO}_{2,5} 5 \mathrm{Br}-\mathrm{H}_{6} \mathrm{~L}^{1,1,4}$ in DMSO- $d_{6}$ between 2.0 and $8.6 \mathrm{ppm}$.

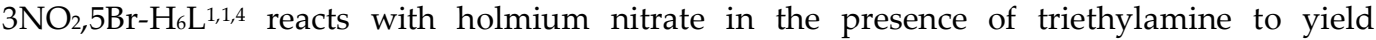
$\mathrm{Ho}\left(3 \mathrm{NO}_{2}, 5 \mathrm{Br}-\mathrm{H}_{3} \mathrm{~L}^{1,1,4}\right)\left(\mathrm{H}_{2} \mathrm{O}\right)(\mathbf{1})$, whose recrystallisation in toluene produces single crystals of the by-product $\left[\mathrm{Ho}\left(3 \mathrm{NO}_{2,5}, 5 \mathrm{Br}-\mathrm{H}_{3} \mathrm{~L}^{1,1,4}\right)\left(3 \mathrm{NO}_{2,5}, 5 \mathrm{Br}-\mathrm{H}_{6} \mathrm{~L}^{1,1,4}\right)\right] \cdot 1.5 \mathrm{CH}_{3} \mathrm{C}_{6} \mathrm{H}_{5} \quad\left(2 \cdot 1.5 \mathrm{CH}_{3} \mathrm{C}_{6} \mathrm{H}_{5}\right) \quad\left(\mathrm{Scheme}_{2}\right)$. Complex 1 was characterised by analytical methods, which agree with the proposed formulation, while the few single crystals of $2 \cdot 1.5 \mathrm{CH}_{3} \mathrm{C}_{6} \mathrm{H}_{5}$ only allowed its crystallographic characterisation. 


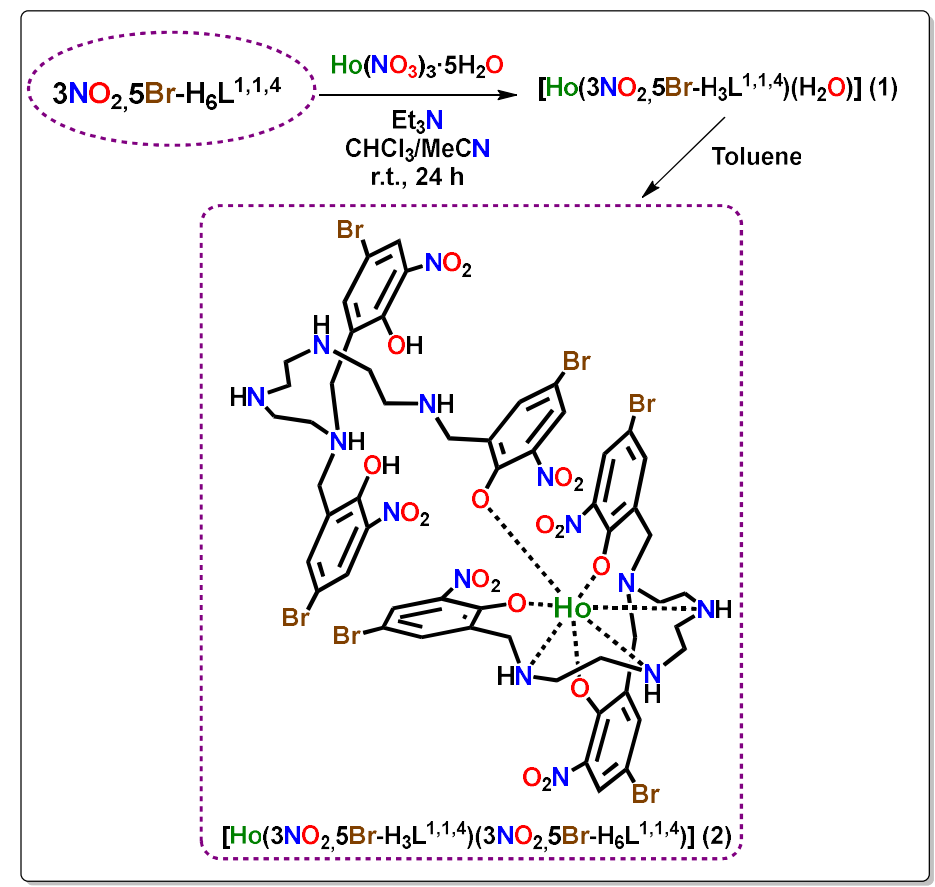

Scheme 2. Reaction scheme for isolation of the metal complexes.

\subsection{Single X-Ray Difraction Studies}

Single crystals of $\left[\mathrm{Ho}\left(3 \mathrm{NO}_{2}, 5 \mathrm{Br}-\mathrm{H}_{3} \mathrm{~L}^{1,1,4}\right)\left(3 \mathrm{NO}_{2}, 5 \mathrm{Br}-\mathrm{H}_{6} \mathrm{~L}^{1,1,4}\right)\right] \cdot 1.5 \mathrm{CH}_{3} \mathrm{C}_{6} \mathrm{H}_{5}\left(2 \cdot 1.5 \mathrm{CH}_{3} \mathrm{C}_{6} \mathrm{H}_{5}\right)$ were obtained as detailed above. An ellipsoid diagram for $\mathbf{2}$ is shown in Figure 2 and main distances and angles are recorded in Table 1.

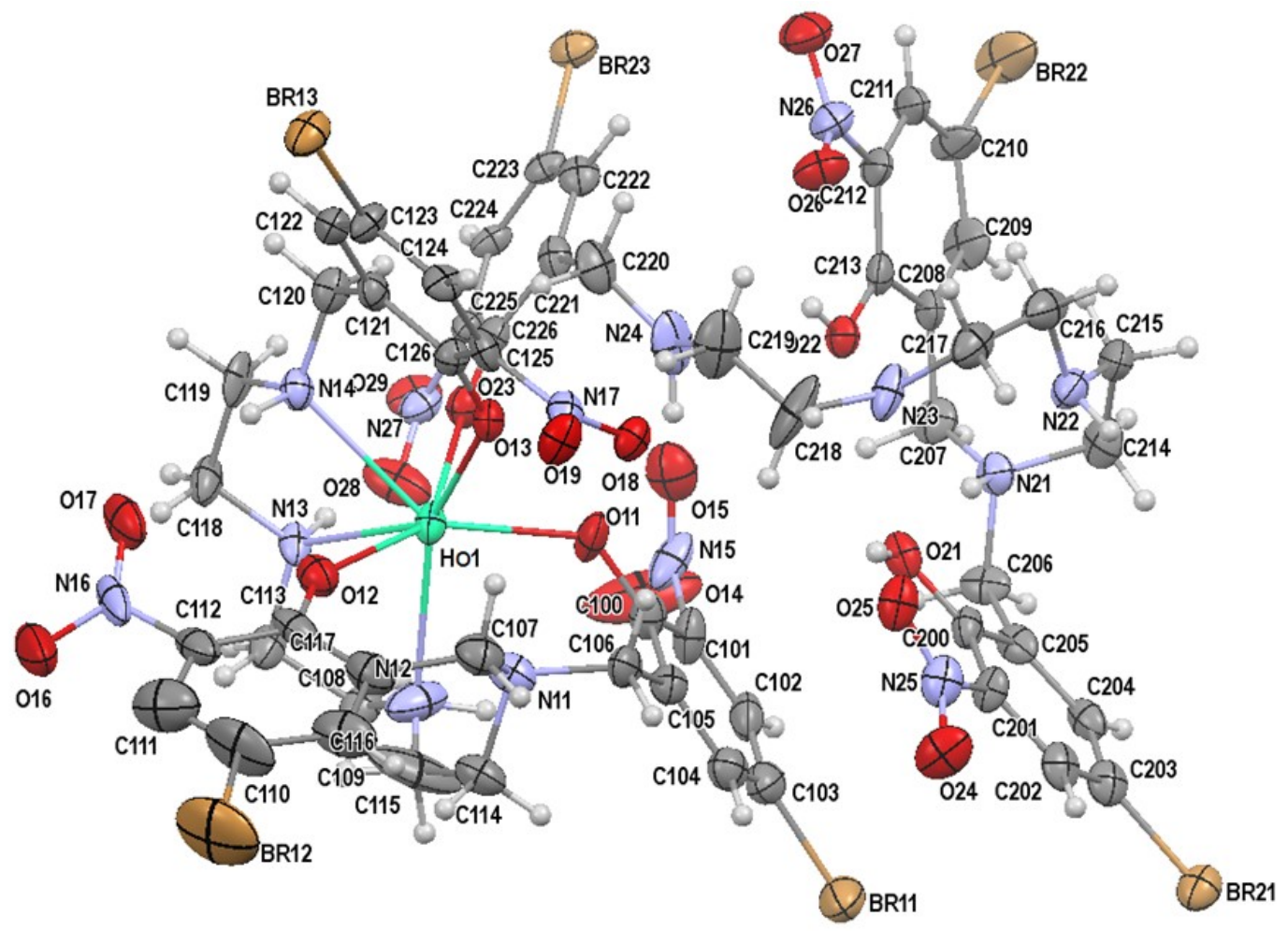

Figure 2. Ellipsoid (30\% probability) diagram for 2. 
Table 1. Main bond distances $(\AA)$ and angles $\left(^{\circ}\right)$ for 2 .

\begin{tabular}{cccc}
\hline Ho1-O11 & $2.247(8)$ & Ho1-O12 & $2.214(9)$ \\
Ho1-O13 & $2.254(8)$ & Ho1-O23 & $2.352(8)$ \\
Ho1-N12 & $2.581(11)$ & Ho1-N14 & $2.547(9)$ \\
Ho1N11 & $2.759(10)$ & Ho1-N13 & $2.502(8)$ \\
N13-Ho1-N12 & $65.3(4)$ & O13-Ho1-N12 & $149.7(3)$ \\
\hline
\end{tabular}

The crystal structure shows that the unit cell is composed of neutral $\left[\mathrm{Ho}\left(3 \mathrm{NO}_{2}, 5 \mathrm{Br}-\mathrm{H}_{3} \mathrm{~L}^{1,1,4}\right)\left(3 \mathrm{NO}_{2}, 5 \mathrm{Br}-\mathrm{H}_{6} \mathrm{~L}^{1,1,4}\right)\right]$ complexes, and toluene as solvate. In the complex, there are two aminophenol ligands joined to the holmium(III) ion. One of them acts as a trianionic hexadentate donor, using all its oxygen atoms and three of the four nitrogen atoms to coordinate to

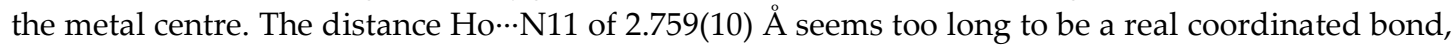
and it should be best considered as a secondary intramolecular interaction [9]. Thus, this ligand provides an $\mathrm{N}_{3} \mathrm{O}_{3}$ environment to the $\mathrm{Ho}^{\mathrm{III}}$ centre. The coordination sphere of the metal ion is completed by an oxygen atom (O23) coming from the second aminophenol ligand, which acts as neutral monodentate.

Curiously, in this second ligand, the coordinated phenol oxygen atom is deprotonated, and the nitrogen (N21) with two benzyl substituents is protonated. Thus, this second neutral aminophenol ligand is a zwitterion, with the charge distribution shown in Scheme 3.

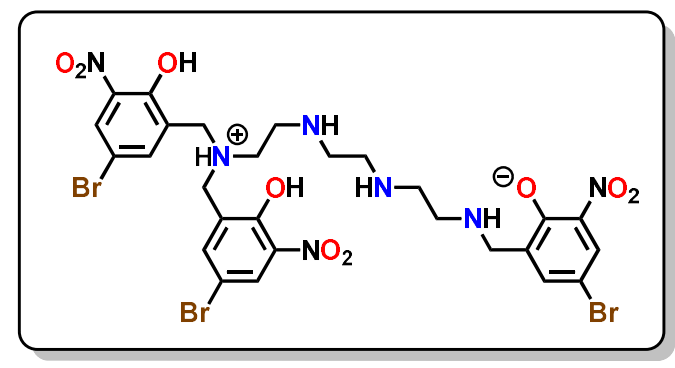

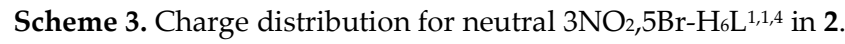

As a result of the described features, $\mathrm{Ho}^{\mathrm{III}}$ reaches coordination number 7 . Calculations of the distortion from an ideal $\mathrm{HoN}_{3} \mathrm{O}_{4}$ core with the SHAPE program [10] indicate that the geometry is closer to a capped trigonal prism.

The main distances and angles about the metal centres agree with those expected for holmium complexes with polydentate N,O donors [9], and this aspect does not deserve further consideration. Nevertheless, it should be noted once again that in this complex one of the aminophenol ligands acts as trianionic hexadentate, and the other one as neutral monodentate. None of these coordination modes have been previously described for this kind of scarcely related aminophenol ligand, which, as far as we know, in the only three previous examples crystallographically characterised $[7,8]$, behaves as trianionic heptadentate. Therefore, this works contributes to increase the knowledge of the coordination chemistry of lanthanoids with a barely reported potentially heptadentate aminophenol ligand.

\section{Conclusions}

This work reports the synthesis and reactivity towards holmium(III) of a new potentially heptadentade aminophenol donor. The ligand could be obtained and isolated with high purity in the

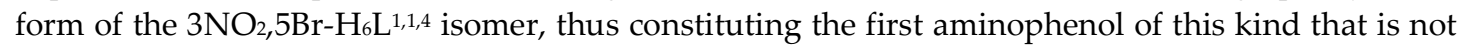

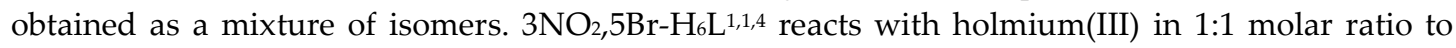
produce the complex $\mathrm{Ho}\left(3 \mathrm{NO}_{2}, 5 \mathrm{Br}-\mathrm{H}_{3} \mathrm{~L}^{1,1,4}\right)\left(\mathrm{H}_{2} \mathrm{O}\right)(\mathbf{1})$, which is unstable in toluene, undergoing rearrangement and yielding $\left[\mathrm{Ho}\left(3 \mathrm{NO}_{2}, 5 \mathrm{Br}-\mathrm{H}_{3} \mathrm{~L}^{1,1,4}\right)\left(3 \mathrm{NO}_{2}, 5 \mathrm{Br}-\mathrm{H}_{6} \mathrm{~L}^{1,1,4}\right)\right] \cdot 1.5 \mathrm{CH}_{3} \mathrm{C}_{6} \mathrm{H}_{5}\left(2 \cdot 1.5 \mathrm{CH}_{3} \mathrm{C}_{6} \mathrm{H}_{5}\right)$ as a by-product. In $\mathbf{2}$, the two ligands act as hexadentate trianionic or monodentate neutral donors, 
coordination modes hitherto unknown for this kind of aminophenol. Accordingly, this research contributes to increase the knowledge in the coordination chemistry of lanthanoids with this type of barely reported donor.

Author Contributions: Conceptualization, M.F., J.C.-V. and A.M.G.D.; methodology, M.F., C.G.-B. and J.C.-V.; analysis of the data, M.F., J.C.-V., J.S.-M. and A.M.G.D.; writing-original draft preparation, M.F. and J.C.-V. All authors have read and agreed to the published version of the manuscript.

Funding: This research was funded by Spanish Ministerio de Innovación, Ciencia y Universidades (PGC2018-102052-B-C21).

Acknowledgments: J.C.-V. acknowledges Xunta de Galicia for his PhD fellowship.

Conflicts of Interest: The authors declare no conflict of interest.

\section{References}

1. Ishikawa, N.; Sugita, M.; Ishikawa, T.; Koshihara, S.; Kaizu, Y. Lanthanide double decker complexes functioning as magnets at the single-molecular level. J. Am. Chem. Soc. 2003, 125, 8694-8695, doi:10.1021/ja029629nv.

2. Rinehart, J.D.; Long, J.R. Exploiting single-ion anisotropy in the design of f-element single-molecule magnets. Chem. Sci. 2011, 2, 2078-2085, doi:10.1039/c1sc00513h.

3. Chen, Y.-C.; Liu, J.-L.; Ungur, L.; Liu, J.; Li, Q.-W.; Wang, L.-F.; Ni, Z.-P.; Chibotaru, L.F.; Chen, X.-M.; Tong, M-L. Symmetry-supported magnetic blocking at $20 \mathrm{~K}$ in pentagonal bipyramidal Dy(III) single-ion magnets. J. Am. Chem. Soc. 2016, 138, 2829 2837.doi:10.1021/jacs.5b13584.

4. Sheldrick, G.M. SADABS: Area-Detector Absorption Correction; Siemens Industrial Automation, Inc.: Madison, WI, USA, 2001.

5. Sheldrick, G.M. Crystal structure refinement with SHELXL. Acta Cryst. 2015, C71, 3-8, doi:10.1107/S2053229614024218.

6. Fondo, M.; García-Deibe, A.M.; Ocampo, N.; Sanmartín, J.; Bermejo, M.R. Insights into the absorption of carbon dioxide by zinc substrates: Isolation and reactivity of di- and tetranuclear zinc complexes. Dalton Trans. 2004, 2135-2141, doi:10.1039/B405744A.

7. Fondo, M.; Corredoira-Vázquez, J.; García-Deibe, A.M.; Sanmartín-Matalobos, J.; Amoza, M.; Botas, A.M.P.; Ferreira, R.A.S.; Carlos, L.D.; Colacio, E. Field-induced slow magnetic relaxation and luminescence thermometry in a mononuclear ytterbium complex. Inorg. Chem. Front. 2020, 7, 3019-3029, doi:10.1039/D0QI00637H.

8. Biswas, S.; Das, S.; Rogez, G.; Chandrasekhar, V. Hydrazone-ligand-based homodinuclear lanthanide complexes: Synthesis, structure, and magnetism Eur. J. Inorg. Chem. 2016, 3322-3329, doi:10.1002/ejic.201600335.

9. (a) Llunell, M.; Casanova, D.; Cirera, J.; Bofill, J.M.; Alemany, P.; Alvarez, S.; Pinsky, M.; Avnir, D.D. SHAPE v1.1b, Barcelona, 2005.

(b) Ruiz-Martínez, A.; Casanova, D.; et al. Polyhedral structures with an odd number of vertices: Nine-coordinate metal compounds. Chem. Eur. J. 2008, 14, 1291-1303, doi:10.1002/chem.200701137.

(c) Llunell, M.; Casanova, D.; Cirera, J.; Alemany, P.; Alvarez, S. SHAPE: Program for the Stereochemical Analysis of Molecular Fragments by Means of Continuous Shape Measures and Associated Tools; University of Barcelona: Barcelona, Spain, 2010.

Publisher's Note: MDPI stays neutral with regard to jurisdictional claims in published maps and institutional affiliations.

(c) 2020 by the authors. Licensee MDPI, Basel, Switzerland. This article is an open access article distributed under the terms and conditions of the Creative Commons Attribution (CC BY) license (http://creativecommons.org/licenses/by/4.0/). 